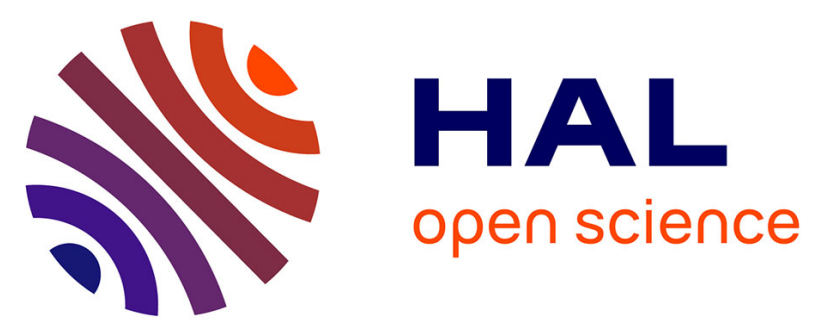

\title{
Contrasted sediment processes and morphological adjustments in three successive cutoff meanders of the Danube Delta
}

\author{
L. Tiron Dutu, M. Provansal, J. Le Coz, F. Dutu
}

\section{- To cite this version:}

L. Tiron Dutu, M. Provansal, J. Le Coz, F. Dutu. Contrasted sediment processes and morphological adjustments in three successive cutoff meanders of the Danube Delta. Geomorphology, 2014, 204, p. 154 - p. 164. 10.1016/j.geomorph.2013.07.035 . hal-01058758

\section{HAL Id: hal-01058758 https://hal.science/hal-01058758}

Submitted on 28 Aug 2014

HAL is a multi-disciplinary open access archive for the deposit and dissemination of scientific research documents, whether they are published or not. The documents may come from teaching and research institutions in France or abroad, or from public or private research centers.
L'archive ouverte pluridisciplinaire HAL, est destinée au dépôt et à la diffusion de documents scientifiques de niveau recherche, publiés ou non, émanant des établissements d'enseignement et de recherche français ou étrangers, des laboratoires publics ou privés. 


\title{
Contrasted sediment processes and morphological adjustments in three successive cutoff meanders of the Danube delta
}

\author{
Laura Tiron Duţu ${ }^{\mathrm{a}^{*}}$, Mireille Provansal ${ }^{\mathrm{b}, 1}$, Jérôme Le Coz ${ }^{\mathrm{c}, 2}$, Florin Duţu $^{\mathrm{a}, 3}$
}

${ }^{a} I N C D$ GEOECOMAR, 23-25 Dimitrie Onciul Street, RO-024053, Bucharest, Romania

${ }^{b} U M R$ 6635, CEREGE-CNRS, Europôle Méditerranéen de l'Arbois, 13545, BP 80, Aix-en-Provence, Cedex 04, France

${ }^{c}$ Irstea, UR HHLY, Hydrology-Hydraulics, 5 rue de la Doua 69100 Villeurbanne, Cedex 9, France

\footnotetext{
*Corresponding author. Tel.: +40-21-252-25-94; Fax: +40-21-252-25-94; E-mail: laura.dutu@geoecomar.ro.

${ }^{1}$ E-mail: provansal@cerege.fr.

${ }^{2}$ E-mail: jerome.lecoz@irstea.fr.

${ }^{3}$ E-mail: fdutu@geoecomar.ro.
} 


\section{Abstract}

Since the 1980s intensive anthropogenic disturbances have affected the channel of the St. George branch, the southern distributary of the Danube River. The meander cutoff program since 1984-1988 induced different hydrosedimentary impacts on the local distribution of river flow velocities, discharge, and sediment fluxes between the former meanders and the man-made canals (Ichim and Radoane, 1986; Popa, 1997; Panin, 2003).

This paper selects three large cutoff meander reaches of the St. George branch (the Mahmudia, Dunavăţ de Sus, and Dunavăţ de Jos meanders noted here as M1, M2, and M3, respectively) as an example to analyse the human impact in the Danube River delta. The diversion of the flow induces strong modifications by acceleration of the fluxes through the artificial canals combined with dramatically enhanced deposition in the former meander where observed in two cases (M1 and M3) and slight modifications in M2. An exceptional flood that occurred in April 2006 offered a good opportunity for scanning different cross sections of the meander systems. Bathymetry, flow velocity, suspended-load concentration, and liquid and solid discharge data were acquired throughout several cross sections of both natural channels and artificial canals of the three cutoffs, using acoustic Doppler current profiler (ADCP) technology, in order to investigate the distribution of the flow and sediment and its impact on the hydrosedimentary processes in each channelized reach and adjacent former meander. Therefore, the results obtained during the 2006 flood were referred to a long-term evolution (1970-2006), analyzed by GIS technics.

Keywords: hydrosedimentary processes; river morphodynamics; cutoff meander; river training; Danube delta; acoustic Doppler current profiler (ADCP)

\section{Introduction}

Morphological processes of the fluvial channel are controlled by liquid and solid fluxes through hydraulic forces exerted by the flow and sediment transport, erosion, and deposition, especially in the flood regime (Bridge, 2003). The geomorphologists particularly underlined the effectiveness of the bankfull discharge, renowned as the most morphogenic, i.e., the main 
long-term control factor of erosion or accumulation of sediments on river banks and bottom channel (Kondolf and Piégay, 2003). In this study, we use the definitions of bankfull proposed by Wolman and Miller (1960) and Leopold et al. (1964): bankfull discharge is the stream flow that fills the main channel and begins to spill water into the active floodplain. The bankfull stage approximates the stage at which the channel and the floodplain begin to be connected (Rosgen, 1994; Knighton, 1996).

The climatic changes and the anthropogenic pressure in the last 100 years have transformed the majority of the river hydrosystems. Distributary network geometry is the most important factor controlling delta landforms (Syvitski et al., 2005) and related hydrological, geological, and sedimentological processes (Hood, 2010). Disturbances like river training operations, such as meander cutoff initiated for navigational or flood mitigation purposes, often lead to dramatic changes in the streamwise profiles (Hooke, 1986; Kesel, 2003; Kiss et al., 2008). The evaluation of long-term effects of a meander cuttof project requires estimation of the long-term geomorphology of both the former meander and the man-made canal. The initial flow and sediment capacity will change with time as the hydraulic efficiency of the flow pathways within the former meander changes owing to the geomorphological evolution. Changes in the river bed associated with modified long-term sediment transport capacity may affect the stage-discharge relationship at the diversion site (Letter et al., 2008). The impacts of a single, small-scale meander correction may have a minimal effect on the system, but the cumulative effects of a number of small diversions can become significant for the entire system. The paper presented here provides a case study of anthropic changes in the morphogenesis and hydrosedimentary dynamics of a set of rectified meanders. The main objective is estimating the intensity of the human activity impacts to river flow and sediment regime and to observe the different morphological responses. 
This paper expands to two downstream meanders the scope of a previous work about the flow and sediment processes during episodic flooding in the Mahmudia meander (Jugaru Tiron et al., 2009), to underline the contrasting processes and evolution between the three cutoffs, and to look for the relevant factors that explain different responses.

\section{Regional setting}

\subsection{Geographical context}

With a mean annual water discharge of $1365 \mathrm{~m}^{3} \cdot \mathrm{s}^{-1}$ and mean annual suspended sediment flux of $317 \mathrm{~kg} . \mathrm{s}^{-1}$, the St. George branch is the most southern branch of the Danube delta $\left(5600 \mathrm{~km}^{2}\right)$, downstream of the main contributor of fresh water and sediment into the Black Sea, the Danube River. The St. George branch starts out from a bifurcation at Ceatal St. George located $108 \mathrm{~km}$ upstream of the outlet to the Black Sea (Fig. 1) and carries about 24\% of the water discharge and $21 \%$ of the suspended sediment discharge of the Danube (Bondar and Panin, 2000). The banks are bounded by a rich and continuous vegetal coverage (trees, poplars, and reeds). The St. George branch is highly sinuous and still morphologically dynamic as attested by migrating meanders (Popa, 1997; Jugaru et al., 2006; Tiron, 2010) and by the fast evolution of its mouth (Panin, 2003).

The study area consists of three former meanders located in the middle part of the St. George branch (Fig. 1): Mahmudia, Dunavăţ de Sus, and Dunavăţ de Jos meanders, named hereafter M1, M2, and M3, respectively. The M1 is the largest and the most complex meander in the St. George branch. It is located between $\mathrm{km} 84$ and $\mathrm{km} 64$ and results from the river impingement against the Mahmudia hills that deflected the St. George channel into a large meander loop named the Mahmudia-Uzlina meander bend (Panin, 2003). Downstream, meanders M2 and M3 derive from one big fossil meander formed between 9000 and $7200 \mathrm{y}$ BP and degraded over time (Panin, 1976). 


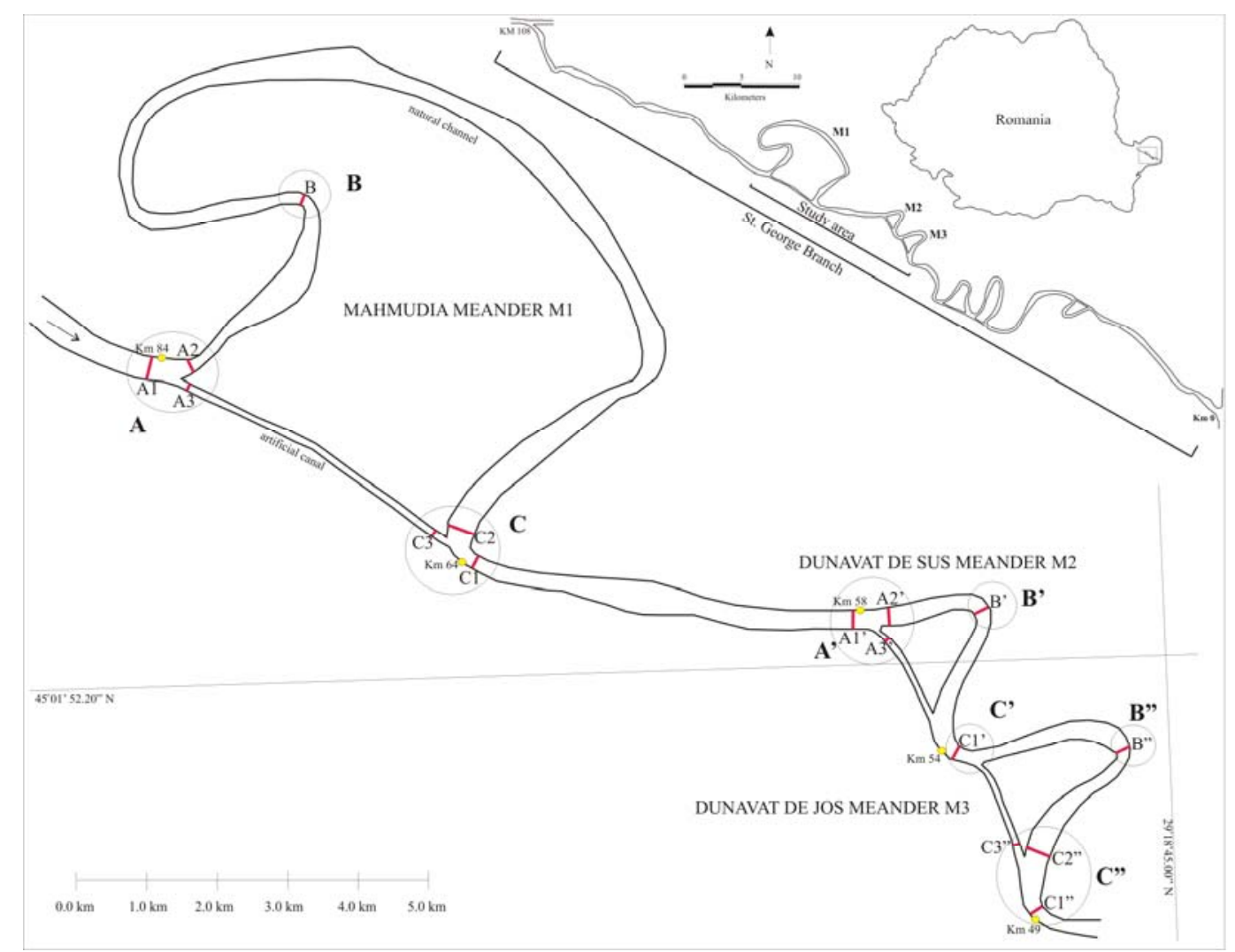

Fig. 1. Location of study reach within the St. George Branch, Danube delta and the ADCP profile position

The sediments of the submerged banks are fine and differently distributed according to the channel type: coarse silt to fine sand (between 20 and $135 \mu \mathrm{m}$ ) along the man-made canals, concave banks, and at the bifurcation/junctions between the natural/artificial channels and clay to fine silt (between 10 and $20 \mu \mathrm{m}$ ) along the former meanders (Tiron and Provansal, 2010).

\subsection{Control factors}

Within the lower Danube, two barrages (Iron Gates I and II, built up in 1970 and 1984, respectively) and the hydrotechnical regulation works along the Danube tributaries have dramatically decreased the sediment discharge at the Danube mouths (within 25-30\%) (Panin and Jipa, 2002; Panin, 2003). 
Along the St. George distributary, the cutoff of the natural channels by navigational canals between 1984 and 1988 caused dramatic changes in the local distribution of river flow velocities, discharge, and sediment fluxes (Ichim and Radoane, 1986; Popa, 1997; Panin, 2003; Tiron, 2010). Such river training works caused a change in the distribution of the solid as well as the liquid discharges in the whole delta, increasing fluxes through the St. George branch (Popa, 1997; Panin and Jipa, 2002; Panin, 2003). Locally, earth dikes (with 2-3 m in height) were built in the 1980s along the banks.

An experimental bathymetrycal survey between 1990 and 1996 (Popa, 1997) showed different initial responses of the three meanders to the cutoff straightening: vertical aggradations in M1 and M3 (maximum rate of $11 \mathrm{~m}$ and $9.6 \mathrm{~m} \cdot \mathrm{y}^{-1}$, respectively) and no important influence of the artificial canal on M2.

In a short period of time (1970-1988), the evolution of the study area was affected by two different impacts: at large and local scales. The reduction of sedimentary discharge, owed to the two most recent dams constructed upstream in the Danube basin (between 1970 and 1984), is overlapped by a shorter and spatially more differentiated evolution, owed to meander straightening (between 1984 and 1988). The two anthropogenic factors (damming and cutoffs) have significantly altered the flow and sediment dynamics of the river network. The former meanders and the newly built channels evolve differently, as a result of the fundamental change of the water and sediment transport processes.

\subsection{Hydraulic conditions during field observations}

The measurements were made at the end of the maximum pick of a flood period that started at the beginning of April 2006 at high spring waters. During the measurements, the Danube flow at its entrance into the delta was $16,500 \mathrm{~m}^{3} \cdot \mathrm{s}^{-1}$, and St. George branch carried 
out $\sim 4600 \mathrm{~m}^{3} \cdot \mathrm{s}^{-1}$. During the measurements (28-30 April 2006), the water flow discharge remained almost constant.

\section{Materials and methods}

\subsection{Hydroacoustic measurements (ADCP)}

The recent application of ADCP (acoustic Doppler current profilers) to river discharge measurements has demonstrated their efficiency and reliability (Yorke and Oberg, 2002). The data analyzed in this study were acquired with an ADCP Workhorse Sentinel $600 \mathrm{kHz}$ (Teledyne RDI) mounted on a power boat (Jugaru Tiron et al., 2009).

During the field campaign, transverse ADCP profiles were systematically completed at relevant sections of the three studied meanders: around the upstream bifurcations (sectors A and $\mathrm{A}^{\prime}$ ), around the downstream confluences (sectors C, C', and C'), and along the cutoff meanders in the apex zones (profiles B, B', and B"). The marks 1, 2, and 3 describe the position of each profile in the sector: location on the natural single upstream channel (1), on the former meander (2), and on the artificial canal (3). In addition to the bottom-track reference used for ADCP velocity and path measurements, the data were continuously georeferenced by a vessel-mounted DGPS (ensemble pivot with mobile Trimble monofrequency ProXR). The bathymetry, water velocity, and discharge data provided by the four beams were handled by means of the WinRiver Teledyne RDI software, version 1.06.

\subsection{Suspended sediment concentrations}

The ADCP records the acoustic backscatter intensity (in $\mathrm{dB}$ ) returned from scattering particles. This intensity is considered as an indicator of suspended-load concentration (SSC; Gartner, 2004; Dinehart and Burau, 2005; Kostaschuk et al., 2005) and by calibration operations is assumed to be reliable enough for further assessment of the SSC distribution 
across sections and SSC flux estimates. The calibration methods for converting the backscatter intensity into suspended sediment concentration (SSC) require extensive sediment sampling operations.

Consequently, in several selected cross sections for this study, stationary ADCP in situ measurements were coupled with water sampling. Technical approaches about the water sampling and calibration methods were developed by Jugaru Tiron et al. (2009). The calibration and post-processing of ADCP data for SSC analysis were conducted using the Sediview software (Land and Jones, 2001).

\subsection{Imagery analyses}

Geographic information system (GIS) tools (MapInfo 6) were used to compare multitemporal topographical maps (between 1970 and 1984) and remote sensing data of Landsat 5 TM (1989) and Landsat 7 ETM+ (2000 and 2006) (Table 1). The TM and ETM+ data had 28, 15, and 20 m pixels. Further details of the map analyses, including estimation of rectification and digization error, have been previously described (Elliott and Gyetvai, 1999; Hood, 2004, 2006; Hughes et al., 2006). The error sources (RMSE) include different spatial resolution of TM and ETM+ data, inaccuracies from manual delineation of banklines, water level differences, effects of vegetation, and other systematic errors. Even collectively considered, the errors are small relative to the magnitude of the overall planform changes observed in the delta (Tiron, 2010). Banks-lines were defined by the abrupt transition from vegetated to unvegetated areas to determine the accretion and erosion areas because of the meander mobility in the period between different image acquisitions. A negative value was interpreted as erosion, a positive value as accretion, and a very low (close to zero) or zero value as stable areas. 


\begin{tabular}{|l|c|c|c|c|c|c|}
\hline $\begin{array}{c}\text { Topographical } \\
\text { maps }\end{array}$ & Source & Date & $\begin{array}{c}\text { Map } \\
\text { scale }\end{array}$ & Projection & $\begin{array}{c}\text { Pixel dimension } \\
(\boldsymbol{m})\end{array}$ & $\begin{array}{c}\text { RMSE } \\
(\boldsymbol{m})\end{array}$ \\
\hline $\begin{array}{l}\text { L-35-107-C } \\
\text { L-35-107-D }\end{array}$ & $\begin{array}{c}\text { Topographical Military } \\
\text { Direction, Romania }\end{array}$ & $1970-1972$ & $1: 50000$ & $\begin{array}{l}\text { Gauss - } \\
\text { Krügger }\end{array}$ & 4 & 4 \\
\hline $\begin{array}{l}\text { L-35-107-C-b } \\
\text { L-35-107-C-d } \\
\text { L-35-107-D-c }\end{array}$ & $\begin{array}{c}\text { Topographical Military } \\
\text { Direction, Romania }\end{array}$ & $1980-1984$ & $1: 25000$ & $\begin{array}{l}\text { Gauss - } \\
\text { Krügger }\end{array}$ & 2 & 4 \\
\hline
\end{tabular}

\begin{tabular}{|l|c|c|r|c|}
\hline \multicolumn{1}{|c|}{ Image type } & Date & $\begin{array}{c}\text { Pixel } \\
\text { dimension }(\boldsymbol{m})\end{array}$ & Canals & $\begin{array}{c}\text { RMSE } \\
(\boldsymbol{\%})\end{array}$ \\
\hline Landsat 5 TM & 20.08 .1989 & 28 & 2,3 and 4 & 9.3 \\
\hline Landsat 7 ETM+ & 06.07 .2000 & 15 & 8 & 5 \\
\hline Landsat 7 ETM+ & 13.08 .2006 & 20 & 2,3 and 4 & 6.6 \\
\hline
\end{tabular}

Table 1. List of the maps and satellite images used for the analysis of the three meanders

\section{Results}

\subsection{Flow and sediment processes at the reach scale}

Authors like Shields and Abt (1989), Constantine et al. (2009), Le Coz et al. (2010), analysed the morphological adjustments of cutoff meanders. They suggested the importance of (i) the channel length (or slope) ratio, (ii) the diversion angle (and shape of the bifurcation edge), and (iii) the bed level difference between both channels. Keeping in mind these indicators (which are linked to the distribution of water and sediment fluxes in the channels), we may draw a specific characterisation of the study reaches, based on the observations acquired during the 2006 flood:

M1-Mahmudia meander. At the nodal point of bifurcation (A1), the water flux balance is conservative. The water discharge A2+A3 $\left(510+2436=2946 \mathrm{~m}^{3} \cdot \mathrm{s}^{-1}\right)$ is roughly equal to the discharge through A1 $\left(2905 \mathrm{~m}^{3} \cdot \mathrm{s}^{-1}\right)$. The cutoff channel of M1 receives only $18 \%$ of the upstream flow. Then, the water discharge slightly decreases along the former meander, from 510 (A2) to $406 \mathrm{~m}^{3} \cdot \mathrm{s}^{-1}(\mathrm{C} 2)$, possibly because of observed outflows to the floodplain and toward small channels starting from the left bank (to the Uzlina lake). The water flow acceleration in the artificial canal (from $1.8 \mathrm{~m} . \mathrm{s}^{-1}$ upstream of the bifurcation to $2.3 \mathrm{~m} . \mathrm{s}^{-1}$ ) (Table 2; Fig. 2) enhances here incision processes, while the liquid and solid fluxes through the former meander are greatly reduced, especially downstream of the first meander apex. In 
the former meander M1, down to very low values favourable to sediment deposition ( 0.8 to $0.1 \mathrm{~m} \cdot \mathrm{s}^{-1}$ between profiles $\mathrm{A} 2$ and $\mathrm{C} 2$ ). Around the apex zone (B), channel asymmetry produces the highest velocities near the concave bank (maximum of $1.2 \mathrm{~m} . \mathrm{s}^{-1}$ ). The former main channel undergoes very visible infilling processes. These processes are attested by the high values of the three mentioned indicators: the ratio between the former channel length and the new channel length (4.4), the diversion angle $\left(\sim 70^{\circ}\right)$, and the bed level difference between A1/A2 of $6.4 \mathrm{~m}$ and between A1/A3 of $-4 \mathrm{~m}$ (Fig. 3).

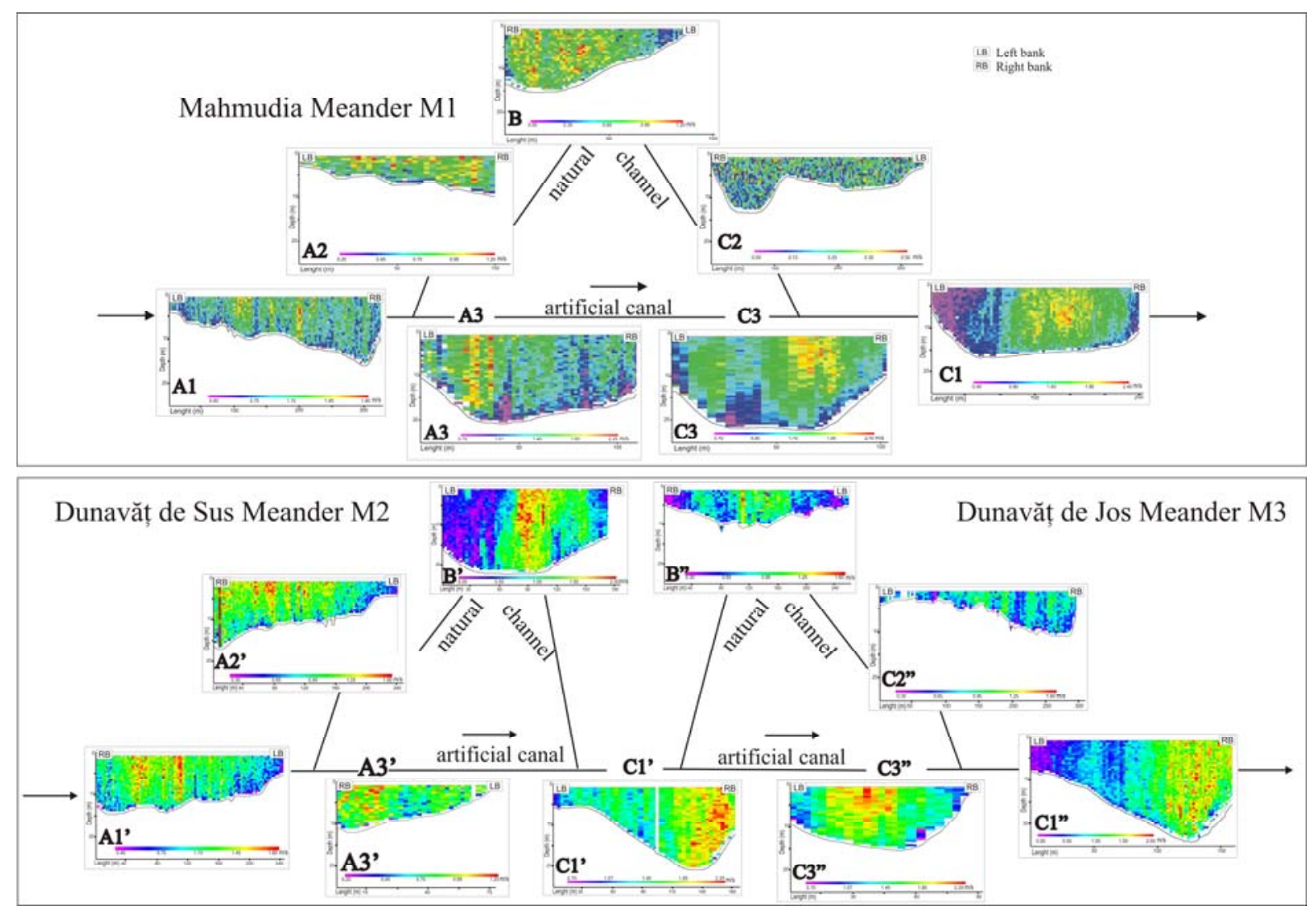

Fig. 2. Distribution of local velocity magnitude within cross sections of the meanders $M 1, M 2$, and $M 3$ 


\begin{tabular}{|c|c|c|c|c|c|c|c|c|c|c|c|c|}
\hline Sector & Section & KM & $\begin{array}{c}\text { Width } \\
\text { (m) }\end{array}$ & $\begin{array}{c}\text { Maximum } \\
\operatorname{depth}(m)\end{array}$ & $\begin{array}{c}\text { Maximum } \\
\text { velocity } \\
\left(m . s^{-1}\right)\end{array}$ & $\begin{array}{c}\text { Mean } \\
\text { velocity } \\
\left(m . s^{-1}\right)\end{array}$ & $\begin{array}{c}\text { Area } \\
\left(m^{2}\right)\end{array}$ & $\begin{array}{c}\text { Liquid } \\
\text { discharge } \\
\left(m^{3} \cdot s^{-1}\right)\end{array}$ & $\begin{array}{c}\text { Flux } \\
\left(\text { kg.s }^{-1}\right)\end{array}$ & $\begin{array}{c}\text { Mean } \\
\text { SSC } \\
\left(m g . l^{1}\right)\end{array}$ & $\begin{array}{c}\omega \\
\left(W \cdot m^{-2}\right)\end{array}$ & $\begin{array}{c}\tau_{0} \\
\left(N \cdot m^{-2}\right)\end{array}$ \\
\hline \multicolumn{13}{|c|}{ MAHMUDIA MEANDER (M1) } \\
\hline \multirow{3}{*}{$A$} & $A 1$ & 84.5 & 362 & 16.3 & 1.8 & 0.9 & 3312 & 2905 & 338 & 120 & 14.1 & 15.5 \\
\hline & $A 2$ & 84.0 & 99 & 9.9 & 1.3 & 0.8 & 650 & 510 & 73 & 140 & 2.2 & 2.7 \\
\hline & $\overline{A 3}$ & 84.3 & 100 & 20.8 & 2.2 & 1.4 & 1790 & 2436 & 246 & 100 & 34.4 & 24.1 \\
\hline$B$ & $B$ & 81.0 & 90 & 15.5 & 1.2 & 0.7 & 938 & 642 & 70 & 110 & 3.3 & 4.9 \\
\hline \multirow{3}{*}{ C } & $C 1$ & 63.6 & 183 & 16.9 & 2.5 & 1.2 & 2708 & 3241 & 422 & 130 & 27.2 & 22.0 \\
\hline & $C 2$ & 64.3 & 347 & 13.2 & 0.5 & 0.1 & 2626 & 406 & 8 & 20 & 0.4 & 4.1 \\
\hline & C3 & 64.5 & 145 & 22.2 & 2.3 & 1.2 & 2143 & 2655 & 336 & 130 & 29.8 & 23.4 \\
\hline \multicolumn{13}{|c|}{ DUNAVAT DE SUS MEANDER (M2) } \\
\hline \multirow{3}{*}{$A^{\prime}$} & $A 1^{\prime}$ & 58.4 & 282 & 14.5 & 1.7 & 1.0 & 2621 & 2650 & 328 & 124 & 3.9 & 6.8 \\
\hline & A2' & 58.0 & 246 & 16.5 & 1.6 & 0.9 & 2332 & 2220 & 300 & 135 & 2.1 & 4.4 \\
\hline & A3' & 57.8 & 80 & 12.4 & 1.2 & 0.7 & 566 & 400 & 45 & 113 & 2.1 & 5.1 \\
\hline$B^{\prime}$ & $B^{\prime}$ & 56.5 & 207 & 22.5 & 2.1 & 0.6 & 3200 & 2080 & 255 & 123 & 2.4 & 5.3 \\
\hline$C^{\prime}$ & C1' & 54.3 & 183 & 21.1 & 2.1 & 1.1 & 2451 & 2640 & 214 & 81 & 3.4 & 4.8 \\
\hline \multicolumn{13}{|c|}{ DUNAVAT DE JOS MEANDER (M3) } \\
\hline B” & B” & 51.7 & 173 & 12.1 & 1.3 & 0.6 & 1710 & 1047 & 172 & 164 & 0.9 & 2.2 \\
\hline \multirow{3}{*}{$C ”$} & C1” & 49.2 & 175 & 24.6 & 2.2 & 0.9 & 2662 & 2394 & 273 & 114 & 5.6 & 10.2 \\
\hline & $C 2 "$ & 49.7 & 336 & 11.3 & 1.5 & 0.6 & 1774 & 1083 & 180 & 166 & 0.7 & 2.7 \\
\hline & C3" & 49.8 & 80 & 15.1 & 1.2 & 1.3 & 1024 & 1342 & 145 & 108 & 6.9 & 6.8 \\
\hline
\end{tabular}

Table 2. Hydrodynamical and sedimentary parameters in investigated cross-sections

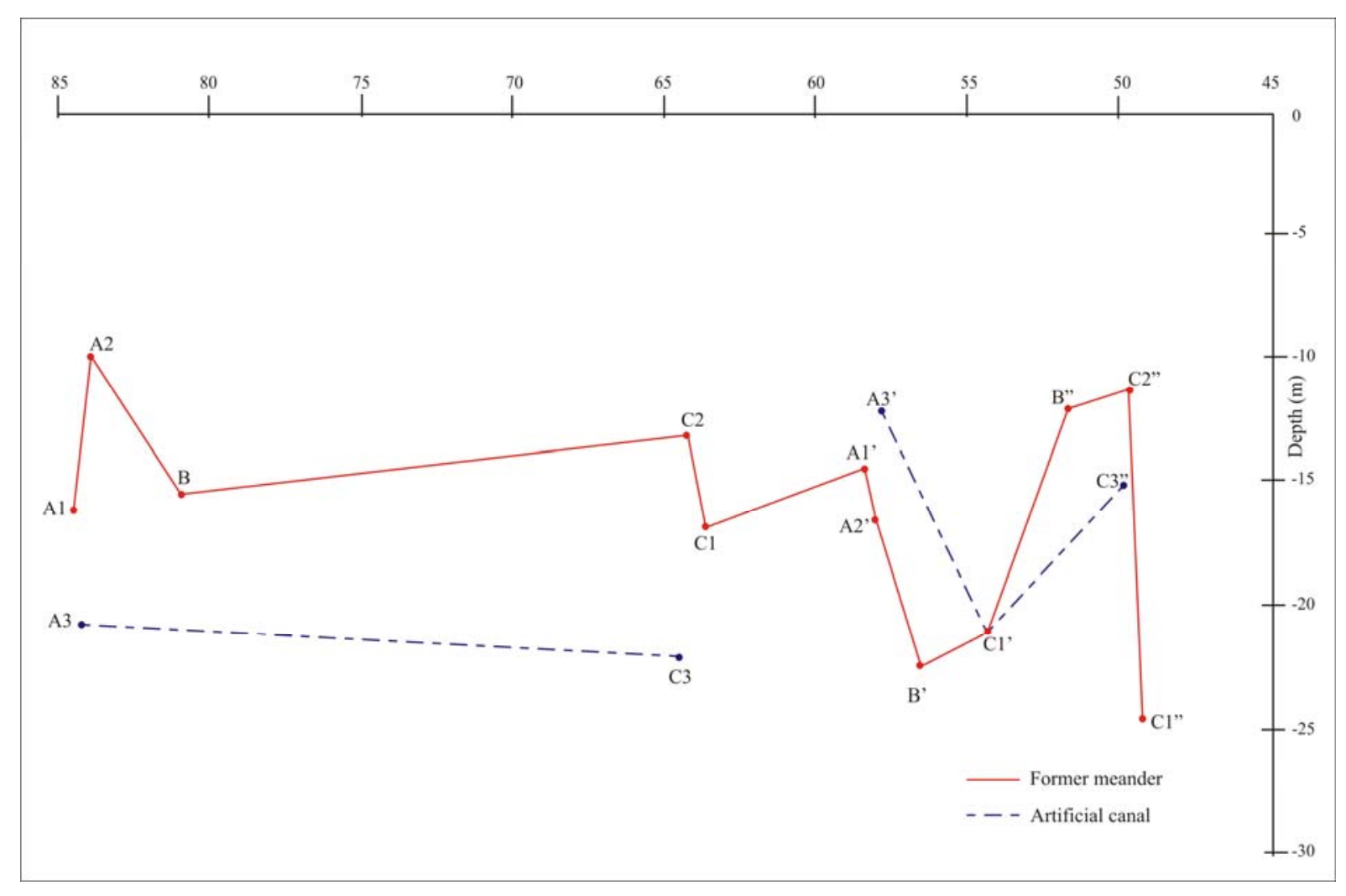

Fig. 3. The thalweg along the natural channel (A1-C1") and the artificial canal (A3-C3, $A 3$ '-C1'C3”). 
M2 - Dunavăț de Sus meander. The cutoff branch M2 takes over $85 \%$ of the water discharge. The sum of the liquid fluxes of the two branches A2' + A3' $(2220+400=2620$ $\left.\mathrm{m}^{3} \cdot \mathrm{s}^{-1}\right)$ is lower but comparable with $\mathrm{A1}$ ', upstream of the bifurcation $\left(2650 \mathrm{~m}^{3} \cdot \mathrm{s}^{-1}\right)$. The water flow acceleration in the natural channel shows the presence of incision processes at the bifurcation sector (A1'-A2') certified by the high velocities values, the low bed level difference between the two sections $(-2 \mathrm{~m})$, the ratio between the former channel length and the new channel length (2.06), and by the value of the diversion angle $\left(\sim 10^{\circ}\right)$. Downstream, along the artificial canal, the bed level difference is positive between A1' and A3' $(2.1 \mathrm{~m})$. The ADCP image confirms the presence of the gravitationally related sedimentary flow (Fig. 4). Downstream, through the former meander, both water and sedimentary flows are diminished. The apex zone (B') is an incision active zone characterised by high velocities (between 1.2 and $2.2 \mathrm{~m} \cdot \mathrm{s}^{-1}$ in the central part), but even along the former meander the maximum velocity is high (1.6 $\mathrm{m} . \mathrm{s}^{-1}$ in A2') (Table 2; Fig. 2). We may suppose that this zone provides the sediment supply for the next section.

M3 - Dunavăţ de Jos meander. The water fluxes at the bifurcation of the M3 are distributed almost equally between the former meander $\left(\mathrm{B}=1047 \mathrm{~m}^{3} \cdot \mathrm{s}^{-1}\right)$ and the artificial canal $\left(C 3 "=1342 \mathrm{~m}^{3} \cdot \mathrm{s}^{-1}\right)$, with a slightly higher flux in the artificial canal $(\approx 56 \%$ of total $)$. The almost equal distribution of the water flow between the two channels involves erosion processes localized in the first part of the former meander (between C1' and B'), but also in the apex zone (B") and a low sedimentation in the second downstream part (between B" and C2"). The high velocity values (between 1.2 and $1.6 \mathrm{~m} \cdot \mathrm{s}^{-1}$ ) enhance gravitationally related sedimentary flow with high concentration $\left(\sim 160 \mathrm{mg} . \mathrm{l}^{-1}\right)$. In the former meander M3, the velocity is reduced in the apex zone (maximum of $1.3 \mathrm{~m} \cdot \mathrm{s}^{-1}$ in B") and also upstream of the confluence (maximum of $1.4 \mathrm{~m} \cdot \mathrm{s}^{-1}$ in $\left.\mathrm{C} 2 "\right)$. The junction zone (C2"-C1") corresponds to a diminishing of the sediment concentrations $\left(\sim 110 \mathrm{mg} \cdot \mathrm{l}^{-1}\right)$. The ratio between the former 
channel length and the new channel length is 2.73 , the diversion angle $\sim 50^{\circ}$, and the bed level difference is positive between $\mathrm{C} 1$ '/B" at $9 \mathrm{~m}$ and also between $\mathrm{C} 1$ '/C3" at $6 \mathrm{~m}$ (Fig. 3).

\subsection{Sedimentary concentrations patterns}

The distribution of SS concentrations varies with every investigated section, depending on the local morphology. On the symmetrical sections A3, C3, and C3" (Fig. 4), the concentrations are found to be higher near the bed $\left(>180 \mathrm{mg} \cdot \mathrm{l}^{-1}\right)$ and the banks and lower (< $60 \mathrm{mg} .1^{-1}$ ) near the free-surface and the central part of the channel.
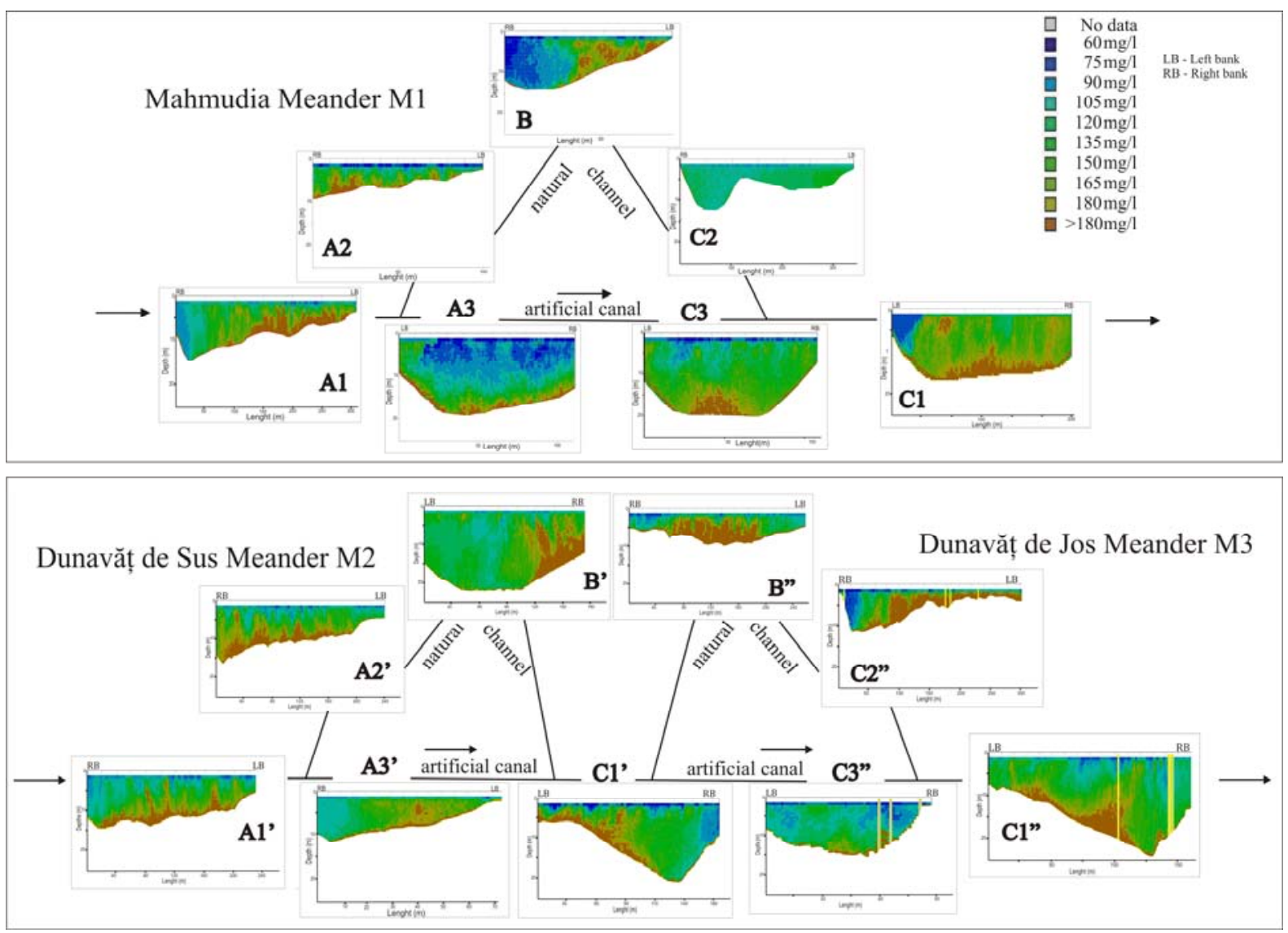

Fig. 4. Distribution of local SSC within cross sections of the meanders M1, M2, and M3

The sections situated near the bifurcations (A1, A3, A1', A3', and C'), in the apex of the former meanders (B, B', and B") and close to the confluence (C1, C3, C1", and C3"), are 
characterized by the presence of SSC plumes issued from the resuspension of bed material (Fig. 4). The concentrations range between minimal values of 10-20 mg. $\mathrm{l}^{-1}$ and maximal

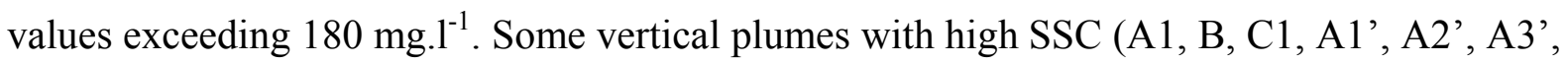
B', B", C3", C2", and C1") suggest that gravitationally related sedimentary flows are eroding sediments from the bottom layer. They are localized near the less steep slopes of convex banks (sections A1, B, and B') and also in deep sections (C1, C3, and C1").

\subsection{Sediment budget}

The total suspension fluxes through each investigated cross section (Table 2; Fig. 4) can be compared by drawing a balance (cf. Fig. 5) of the ways of transport and of their relationship to the hydrodynamics and morphology of the channel.
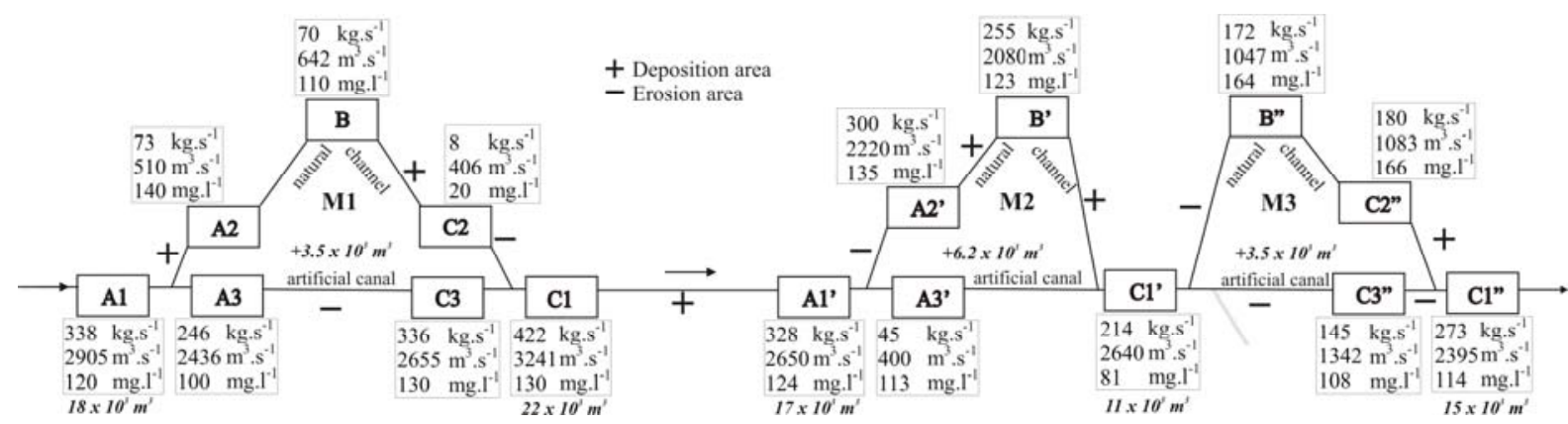

Fig. 5. A box model for SS fluxes, liquid discharge, and SSC by section through the study area and the balance of the sedimentary transit for each meander

On M1, Fig. 5 shows that most of the sedimentary flux $(\approx 73 \%)$ passes through the artificial canal (between A3 and C3). The sedimentary flux supply at the exit of the artificial canal shows erosion processes between A3 and C3. The loss of sediments between cross sections A2+A3 $\left(73+246=319 \mathrm{~kg} \cdot \mathrm{s}^{-1}\right)$ and section A1 $\left(338 \mathrm{~kg} \cdot \mathrm{s}^{-1}\right)$ is $19 \mathrm{~kg} \cdot \mathrm{s}^{-1}$. This relative variation, $<6 \%$, is not significant in comparison with measurement uncertainties. 
In the former meander M1, the sediment transit is weak and progressively decreases with distance, from 73 (A2) to $8 \mathrm{~kg} \cdot \mathrm{s}^{-1}(\mathrm{C} 2)$, indicating an obvious siltation in the main channel (aggradation of the river bed and banks, development of islands rapidly fixed by the riparian forest). The flow and sediment flux issuing from the meander lose 104 and $65 \mathrm{~kg} . \mathrm{s}^{-1}$ in comparison to the flow entering the meander. The high SSC values appear again downstream of the confluence $(\mathrm{C} 1)$.

The SSC values confirm this evolution: the SSC increases between A3 and C3 from 100 to $130 \mathrm{mg} \cdot \mathrm{l}^{-1}$ (indicator of erosion) and decreases between A2 and C2 from 140 to $20 \mathrm{mg} . \mathrm{l}^{-1}$ (indicator of deposition). The high value of SSC in A2 (140 mg. $\left.1^{-1}\right)$ can be explained by the active bed dynamics at the bifurcation area.

The flow decrease $\left(\approx 590 \mathrm{~m}^{3} \cdot \mathrm{s}^{-1}\right)$ between sections $\mathrm{C} 1$ and $\mathrm{A} 1$ ' is by reason of an export toward the Murighiol canal in the right bank. Downstream, at the entrance in M2, the artificial canal is taking only $\sim 15 \%$ from the total sedimentary flux. The remaining flux $(\sim$ $85 \%)$ passes through the former meander $\mathrm{M} 2$. At the bifurcation $\left(\mathrm{C} 1^{\prime}\right)$, there is a quasiequality in the distribution of the fluxes between the artificial canal (C3") and the former meander (B"). But the sum of the sedimentary fluxes A2'+A3' $\left(300+45=345 \mathrm{~kg} . \mathrm{s}^{-1}\right)$ is higher by $17 \mathrm{~kg} . \mathrm{s}^{-1}$ than the input A1' $\left(328 \mathrm{~kg} . \mathrm{s}^{-1}\right)$. This low difference shows possible erosion in the bifurcation area, but it also could be explained by the potential measurement uncertainties. The retention of $34 \%$ of the sedimentary input in the former meander indicates a deposition area, localized precisely in the downstream sector.

In M3, the sum of output C2" $+\mathrm{C} 3$ " $\left(180+145=325 \mathrm{~kg} \cdot \mathrm{s}^{-1}\right)$ is significantly greater than the input flux C1' $\left(214 \mathrm{~kg} \cdot \mathrm{s}^{-1}\right)$. This difference shows a sedimentary supply of $111 \mathrm{~kg} . \mathrm{s}^{-1}$ from the bed or bank erosion between $\mathrm{C} 1$ ' and $\mathrm{C} 3$ " or/and $\mathrm{C} 1$ ' and $\mathrm{C} 2$ ". The former meander receives a reduced solid flux with low SSC $\left(81 \mathrm{mg} . \mathrm{l}^{-1}\right)$; the SS concentrations are increasing 
on natural and artificial channels up to 166 (C2") and $108 \mathrm{mg} . \mathrm{l}^{-1}$ (C3”), which is additional evidence of the erosion processes located in the former meander or in the artificial canal.

The sedimentary fluxes are variable along the three studied reaches. In M1, for an input volume of $\sim 18 \times 10^{3} \mathrm{~m}^{3} / \mathrm{d}(\mathrm{A} 1)$, the output is $\sim 22 \times 10^{3} \mathrm{~m}^{3} / \mathrm{d}(\mathrm{C} 1)$. The sedimentary volume deposited within the former meander between $\mathrm{A} 2$ and $\mathrm{C} 2$ can be estimated at $\sim 3.5 \times 10^{3}$ $\mathrm{m}^{3} / \mathrm{d}$. The total erosion in M1 should therefore be explained by a sediment supply from erosion of the artificial channel around $7.5 \times 10^{3} \mathrm{~m}^{3} / \mathrm{d}$. Five kilometres downstream at the entrance to M2 the sedimentary input volume is $\sim 17 \times 10^{3} \mathrm{~m}^{3} / \mathrm{d}\left(\mathrm{A} 1^{\prime}\right)$, which is $<$ M1 output. The volume of the deposited sediments within the former meanders M2 (between A2' and $\mathrm{C} 1{ }^{\prime}$ ) and $\mathrm{M} 3$ (between $\mathrm{C} 1{ }^{\prime}$ and $\mathrm{C} 2{ }^{\prime \prime}$ ) can be estimated to be, respectively, $\approx 6.22 \times 10^{3}$ and $\approx$ $3.5 \times 10^{3} \mathrm{~m}^{3} / \mathrm{d}$. These results will be discussed later.

\subsection{Overview of imagery analyses}

\subsubsection{Channel width evolution between 1970 and 2006}

Channel widths are the distance from bank edge to the opposite bank edge, measured perpendicular to the channel thalwegs every kilometre streamwise. By superimposition of maps and satellite images, we can draw a first evolution diagram of the channel width between 1970 and 1984 and between 1989 and 2006, i.e., before and after the meanders rectification, respectively (Fig. 6).

Overall, the channel width decreases before the artificial works. Some sections are very active (A2, B, B', C1', and C1") with a maximum of $-5.7 \mathrm{~m} . \mathrm{y}^{-1}$ at $\mathrm{km} 84$ on $\mathrm{A} 2$ ); and others are almost stable, close to the error limit.

After the cutoff works, the narrowing became more intensive. On M1 the retraction is moderate between $\mathrm{km} 86$ and $\mathrm{km} 76\left(-2.5 \mathrm{~m} \cdot \mathrm{y}^{-1}\right)$, more important between $\mathrm{km} 75$ and $\mathrm{km} 72$ $\left(-5.6 \mathrm{~m} \cdot \mathrm{y}^{-1}\right)$ and lower downstream of $\mathrm{km} 71\left(-0.1\right.$ and $\left.-0.5 \mathrm{~m} \cdot \mathrm{y}^{-1}\right)$. Higher values $\left(>-3 \mathrm{~m} \cdot \mathrm{y}^{-1}\right)$ 
are localized in the apex zone at $\mathrm{km} 81$ (B). Downstream, the narrowing of the channels of M2 and M3 is also generalised. The average evolution rate is slightly positive until 1990: enlargement of the channel with a maximum of $1.8 \mathrm{~m}^{-1} \mathrm{y}^{-1}$ at $\mathrm{km} 61$ (on $\mathrm{C} 1$ ); and negative between 1990 and 2000: retraction of the channel with maximum of $-5.1 \mathrm{~m} . \mathrm{y}^{-1}$.

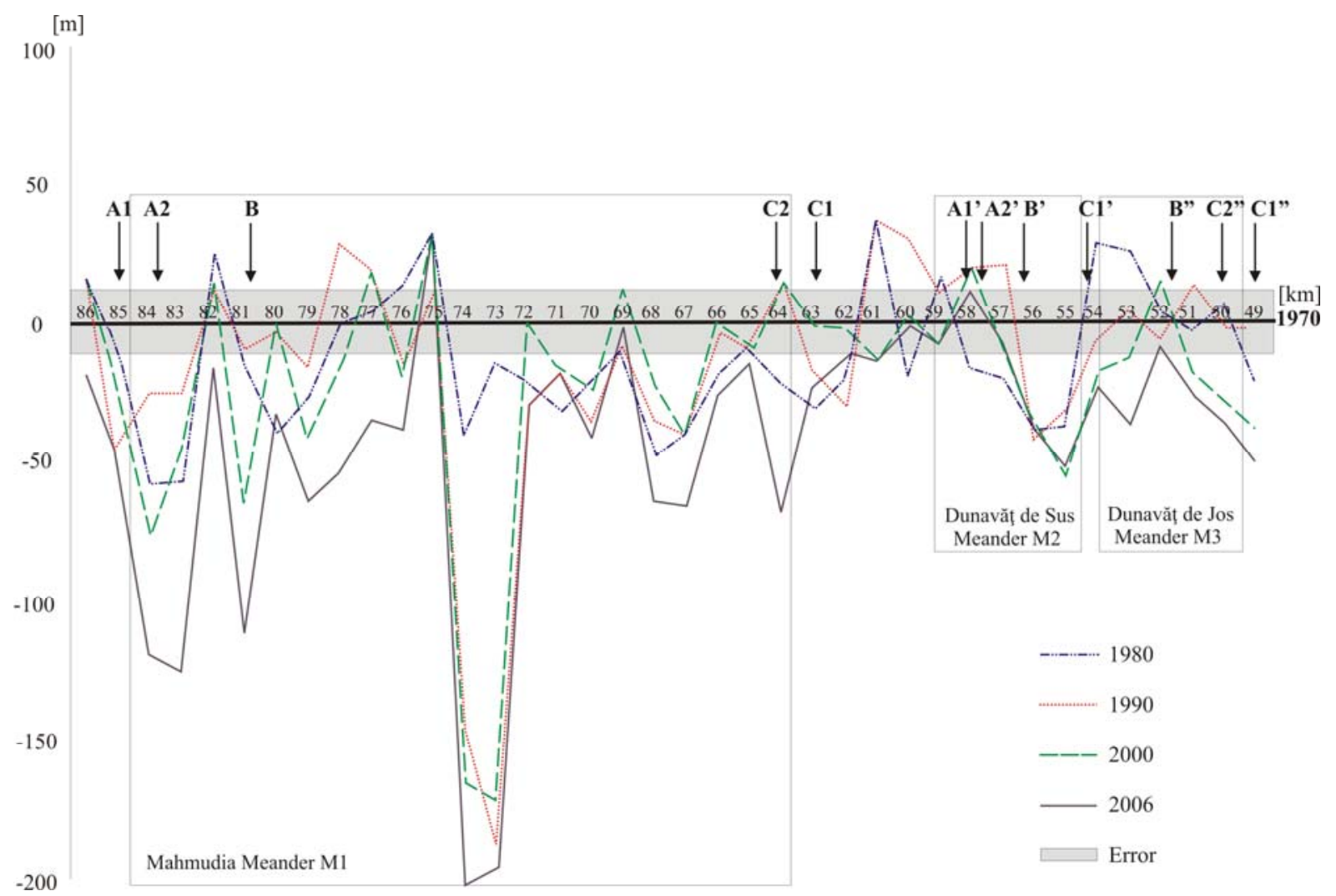

Fig. 6. Channel width evolution of the three meanders between 1970 and 2006 (the values in 1970 are taken equal to zero as the reference situation values)

\subsubsection{Channel mobility between 1970 and 2006}

An indicator of channel behaviour is the lateral shift, involving processes such as bank erosion, bend migration, and channel avulsion (Leys and Werritty, 1999). At the entrance of M1, the channel between $\mathrm{km} 85$ and $\mathrm{km} 79$ is characterized by continuous aggradation on both banks; the channel width was strongly reduced. Sediment infilling is revealed by the creation of many internal islands along the former meander. The morphology of the 
confluence is influenced by the junction with the artificial canal with a progradation of the convex bank at km 64 (Fig. 7).

Downstream, sedimentation is the dominant process, located on both channel banks, along concave, convex, and straight reaches, with a visible preponderance on the left bank (spatial distribution of the flow energy diminished on the left bank). The junction with the artificial canals modifies the channel in the flow direction at $\mathrm{km} \mathrm{54.5.} \mathrm{Locally,} \mathrm{some}$

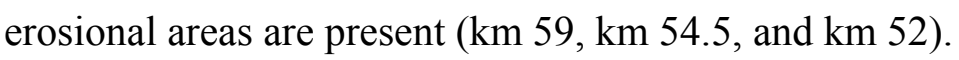

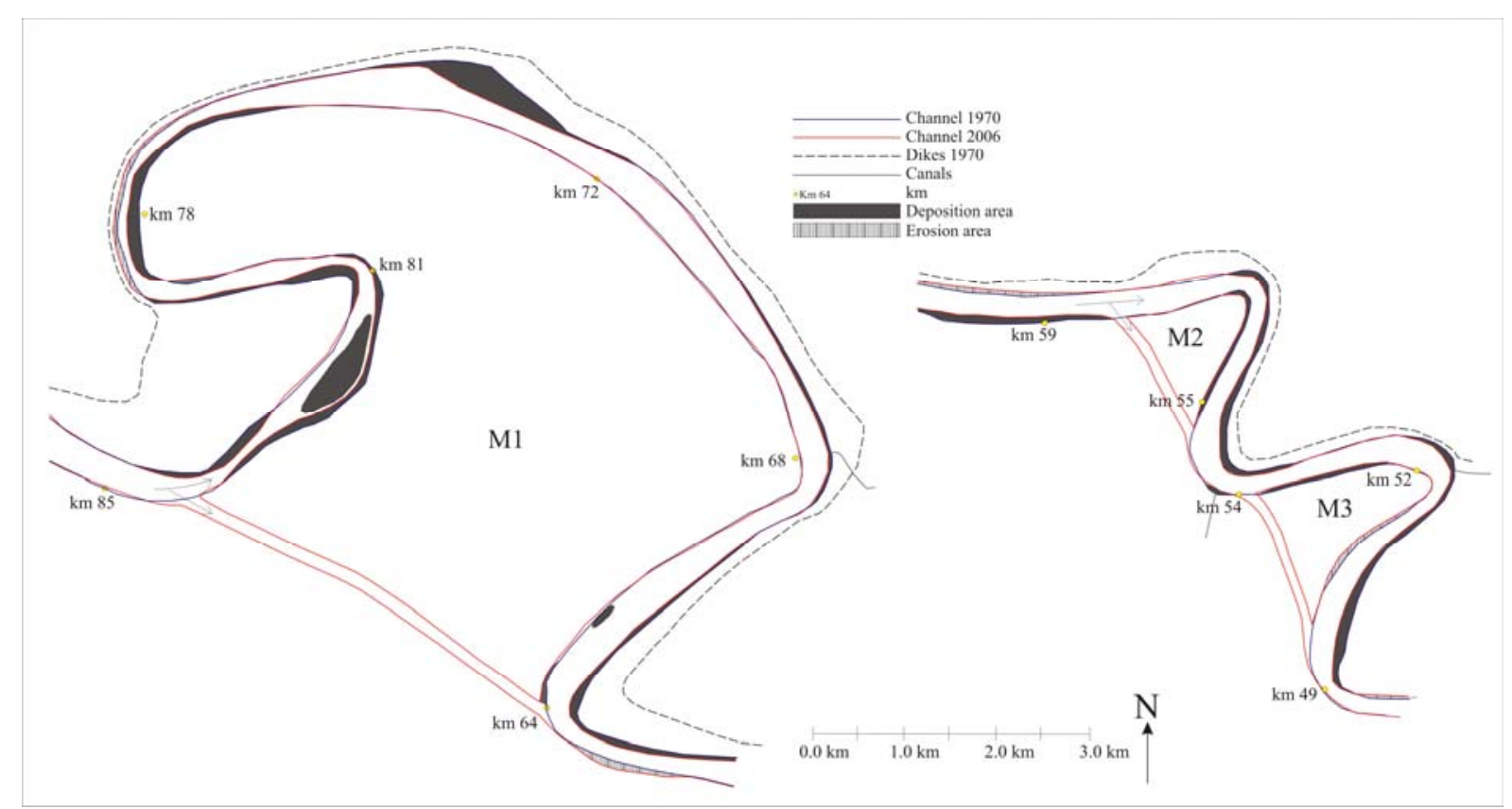

Fig. 7. Channel mobility of the three meanders between 1970 and 2006

The sinuosity of the entire study reach (from $\mathrm{km} 84$ to $\mathrm{km} \mathrm{49,} \mathrm{measured} \mathrm{along} \mathrm{the} \mathrm{natural}$ channel) has increased from 2.43 (1970) to 2.52 (2006). For the same period, the sinuosity of M1 has increase from 4.26 to 4.33 . M2 registered a slight sinuosity decrease (from 1.95 to 1.91), and M3 is the only former meander with stable sinuosity after the cutoff program (Table 3). 
The contrasted behaviours of the three former meanders over the last four decades are summarized as follows: M1 - marked deposits (banks and islands) in the natural channel, with a retraction of the active width; M2 and M3 - still active dynamics (visible migration by accretion of the banks and slight erosion zones).

\begin{tabular}{|c|c|c|c|c|c|}
\hline $\begin{array}{l}\text { Distance from } \\
\text { river mouth } \\
(\mathrm{km})\end{array}$ & $\begin{array}{l}\text { Wavelength } \\
(\mathrm{km})\end{array}$ & $\begin{array}{c}\text { Sinuosity, } S, \text { in } \\
1970\end{array}$ & $\begin{array}{c}\text { Sinuosity, } S, \text { in } \\
2006\end{array}$ & $\begin{array}{c}\text { Diversion angle } \\
\text { ()) }\end{array}$ & $\begin{array}{c}\text { Radius of } \\
\text { curvature, } \\
\text { Rc, in } 2006,(m)\end{array}$ \\
\hline (M1) $84-64$ & 5.1 & 4.26 & 4.33 & $70^{\circ}$ & 728 \\
\hline (M2) $58-54$ & 1.93 & 1.95 & 1.91 & $10^{\circ}$ & 425 \\
\hline (M3) $54-49$ & 2.32 & 2.41 & 2.41 & $50^{\circ}$ & 429 \\
\hline
\end{tabular}

Table 3. Morphometric characteristics of the three meanders (where $S=$ actual path length/shortest path length and diversion angle = angle between the former meander axis and the upstream single channel axis)

\section{Discussion}

Former meanders are generally sediment storage locations (by progressive sedimentation of the channel bed and lateral banks, canals, and overflow). Nevertheless, each meander has a particular hydrosedimentary performance. In our case, there is no similarity between the three consecutive former meanders. The former meander M1 has the particularity of a large and complex cutoff, with two sinuous reaches located downstream of the bifurcation (which induces velocity decreases). At the bifurcation/confluence nodal points and in the artificial canals, a most intense hydrodynamic activity (high flow velocity) is present. These areas represent transit zones and possible sediment sources (by erosional processes) for the downstream areas. Therefore, in each case the artificial canals had a different impact on the meander's evolution, depending on several factors. A full picture of channel shape is composed through the combination of channel sinuosity for particular sections of the channel, channel meander wavelength, radius of curvature, channel width, and channel depth. 


\subsection{Long-term evolution}

Between 1970 and 1984 (the period before the meander's rectification), the evolution of the three meanders is marked by a generally slow retraction, with local enlargement of the channel width.

After 1984, the meander's rectification introduces a rupture of the natural bends evolution, and the narrowing becomes the dominant process. After the meander's rectification, the retraction and the infilling processes are installed (fluvial energy diminished in the cutoffs). The issue of internal islands explains the aggradation of the channel bed.

The effects of the meander's rectification are observed as from the beginning of the work (1984), and they are amplified very fast. On M1, the channel narrowing is the dominant process after 1980 and expresses the progressive energy decrease from upstream to downstream. Between 1970 and 2006, only the sector from $\mathrm{km} 78$ to $\mathrm{km} 81$ of the M1 is still active; here, the progradation of the convex bank is important (between 2.9 and $3.25 \mathrm{~m} / \mathrm{y}^{-1}$, respectively). Downstream, along the former meander, the bank accretion clearly induces a sedimentary deficit to the M2 and M3.

The meanders M2 and M3 are characterised by enlargement of the channel until 1985. After this date and more specifically after 1990, the tendency is the narrowing of the channel and the slight dynamic activity of the apex zones.

Globally, the three meanders present a general and comparable systematization, characterised by the predominance of the incision processes upstream of the apex zones, then infilling processes downstream of the apex zones, while the bifurcations and the junctions are very dynamic areas. However, the intensity and the magnitude of the hydrosedimentary processes seem to be different on each sector, resulting from some local factors described below. 


\subsection{Local control factors governing the distribution of flow energy}

Physically conceptual models to predict the hydraulic and geomorphic conditions for an avulsion process were developed by many authors (Mackey and Bridge, 1995; Slingerland and Smith, 1998; Barbe et al., 2000; Winer and Raphelt, 2005; Edmonds and Slingerland, 2008; Letter et al., 2008). They showed that the avulsion depends on the main channel to former meander channel bed slopes ratio, the bed grain size, water surface elevation at the bifurcation areas, the diversion angle, etc. The results highlight the different ways of operation of the three former meanders: on M1, most of the liquid and sedimentary fluxes pass through the artificial canal; while on M2, the former meander is the principal water and sediment distributor. On M3, there is quasi-equality in the repartition of the liquid and sedimentary fluxes between the two channels. Obviously, the morphological impact of the rectification is variable depending on several local factors:

- The position of the study area along the St. George branch: there is a chaining in the processes development: for M1, the sediment infilling processes induce a sedimentary deficit for the downstream sector (M2 and M3), where the sedimentation started up later (in the 1990s). Here, situated upstream, M2 seems to be more active than M3.

- The diversion angle, or the angle between the main channel and the entrance to a diversion channel, is an important control on the division of the flow's momentum, and thus also on the ability of flow in the diversion to transport bed material (Law and Reynolds, 1966; Hager, 1984). Results from flume experiments reveal that discharge in the diversion is progressively reduced with increases in the diversion angle above $50^{\circ}$ (Vanoni, 1975).

The results show that the flow in a former meander with a diversion angle lower than $50^{\circ}$ $\left(\mathrm{M} 2=10^{\circ}\right.$ and $\left.\mathrm{M} 3=50^{\circ}\right)$ has higher capacity to carry out sedimentary material, and thus the aggradation of bed material at the entrance and along the cutoff is mitigated (M3) or even absent (M2). Such former meander types are hydraulically connected to the main channel. On 
the other hand, flow in a cutoff with a high diversion angle $\left(\mathrm{M} 1=70^{\circ}\right)$ is less able to transmit sedimentary material, which thus promotes the development of sediment infilling processes at the entrance and along the cutoff.

- The $\mathbf{L} / \mathbf{l}$ ratio (ratio between the length of the former meander and the artificial canal length L/l). The impact magnitude of the rectifications depends on the ratio between the lengths of the artificial canal and the former meander, which scales with the loss of flow energy in the former meander. The values range between 2.06 (M2) and 4.4 (M1) with an intermediary value of $2.73(\mathrm{M} 3)$.

- The bed level difference at the bifurcation areas confirms the identified hydrosedimentary processes in the studied meanders. Negative values reflect the presence of local erosional processes and consequently enhancement of the liquid and sedimentary flows (A1-A3, A1'A2'). On some reaches with positive values (A1-A2, A1'-A3'), the flow is reduced and infilling processes are located. On M3, the positive bed level deference on both channels (between $\mathrm{C} 1$ '-B' and $\mathrm{C} 1$ '-C3') has as a consequence the equality in the flows repartition, with a slight preponderance to the artificial canal where the bed level difference is lower.

- The sinuosity is an important morphological indicator to the channel evolution after the cutoff program. Flow volume and velocity, effects of channel curvatures on flows, sediment load and grain size, channel bank cohesiveness, and initial morphologies of channels (e.g., width and width-to-depth ratios) are the primary controlling factors of sinuosity evolution (Schumm, 1977, 1981, 1985; Miall, 1996; Ethridge and Schumm, 2007). For our sector, the increase of this index from 2.43 before the cutoff program (1970) to 2.52 in 2006 corresponds to a reduction of the energy of the river.

Separately, the three studied meanders have a slightly different evolution of sinuosity: M1 experienced an important increase of sinuosity (from 4.09 in 1970 to 4.4 in 2006). The sinuosity increase combined with the L/1 ratio and with the high value of the diversion angle 
explains the former meander aggradation. M2 and M3 show slow variations of the sinuosity along this period: from 1.9 in 1970 to 1.84 in 2006 for M2, and from 2.28 in 1970 to 2.36 in 2006 for M3.

\subsection{Event-scale morphodynamical analysis}

The assessment of the sediment transport capacity during the 2006 flood are analyzed through the concept of the specific stream power (Bagnold, 1966), indicating the stream's ability to adjust its channel morphology (Biedenharn et al., 2000), and the boundary shear stress, indicating the flow capacity to mobilize sediment from the bed as suspended-load or bedload.

$\omega=\Omega / \mathrm{W} \quad\left(\mathrm{W} \cdot \mathrm{m}^{-2}\right)$

where $B$ is the bankfull channel width, and $\Omega$ is the stream power that writes:

$\Omega=\rho_{w} g Q S\left(\mathrm{~W} \cdot \mathrm{m}^{-1}\right)$

where the representative discharge $Q\left[\mathrm{~m}^{3} \cdot \mathrm{s}^{-1}\right]$ is usually taken as the bankfull discharge $Q b f$. In the present analysis, the discharge gauged by $a D c p$ for each channel is considered as the representative discharge. As for bed shear stress estimates (see below), the energy slope $S$ is approximated by the observed mean water slope.

The specific stream power is actually a complex index, especially when applied to meandering systems, where the water slope is influenced by the sinuosity and variations of the width of the channel (Schmitt et al., 2001). Any change in the magnitude of flow, by cause of a diversion, has a direct impact on stream power. In the case of river diversions, as flow is diverted from the main channel, the stream power of the main channel is reduced, resulting in a reduction in the ability of the flow to do work at a given rate; i.e., a reduction in the ability of the main channel flow to transport sediment (Letter et al., 2008). 
The results located high specific stream power values (above $30 \mathrm{~W} \cdot \mathrm{m}^{-2}$ ) in the artificial canal of M1 (A3 and C3; Table 2) and at the confluence (C3) because of low width and steep slope. In the artificial canals of $\mathrm{M} 2$ and $\mathrm{M} 3, \omega$ values are quite low (from $3.9 \mathrm{~W} . \mathrm{m}^{-2}$ in $\mathrm{A} 1$ ' to 6.9 W.m ${ }^{-2}$ in $\mathrm{C} 3$ "). In the former meanders, stream power values are logically much lower because of the lower slope and longer length (A2 to $\mathrm{C} 2$ and $\mathrm{A} 2$ ' to $\mathrm{C} 1$ ': below $3.5 \mathrm{~W} . \mathrm{m}^{-2}$; $\mathrm{C} 1$ ' to C2": below $1 \mathrm{~W} \cdot \mathrm{m}^{-2}$ ).

The mean bed shear stress $\left(\tau_{0}\right)$ corresponds to the unit tractive force exerted on the bed:

$\tau_{0}=\rho g R S \quad\left(N . m^{-2}\right)$

where $\rho$ is the fluid density (1000 kg.m ${ }^{-3}$ for sediment-free water), $g$ is the gravitational acceleration $\left(9.81 \mathrm{~m} . \mathrm{s}^{-2}\right), R$ is the hydraulic radius $[\mathrm{m}], S$ is the water energy slope $\left[\mathrm{m} . \mathrm{m}^{-1}\right.$ ] (i.e., $\mathrm{S}=0.056 \mathrm{~m} \cdot \mathrm{km}^{-1}$ in the former meander of $\mathrm{M} 1(\mathrm{~A} 2-\mathrm{C} 2), \mathrm{S}=0.024 \mathrm{~m} \cdot \mathrm{km}^{-1}$ in the former meander of M2 and M3 (A2'-C2"), and S $=0.174 \mathrm{~m} \cdot \mathrm{km}^{-1}$ in the artificial canal of M1 $(\mathrm{A} 1-\mathrm{C} 1), \mathrm{S}=0.042 \mathrm{~m} \cdot \mathrm{km}^{-1}$ in the artificial canal of M2 and M3 (A1'-C1”)).

The values of $\tau_{0}$ are generally in good agreement with the stream power values. The shear stress is significantly higher in the artificial canals but with different intensity from one meander to another (A3-C3 above $22 \mathrm{~N} . \mathrm{m}^{-2}$ in M1 and between 6.8 and $10.2 \mathrm{~N} . \mathrm{m}^{-2}$ in M2 and M3) (Fig. 8).

In the former meanders, shear stress values are dramatically lower (below $2.7 \mathrm{~N} . \mathrm{m}^{-2}$ in $\mathrm{A} 2$, B", and C2" and between 4.1 and 4.9 N.m ${ }^{-2}$ in B, C2, A2', and C1). The apex of M1 and M2 (at sections B and B') corresponds to the most active reaches in the former meanders. The sedimentary dynamics are dramatically reduced in the former meander of M3. Globally, bed shear stress values indicate high erosion capacity in the artificial canal and lower and decreasing erosion capacity in the former meanders (deposition reaches) but with some evidenced differences between the three consecutive meanders. 


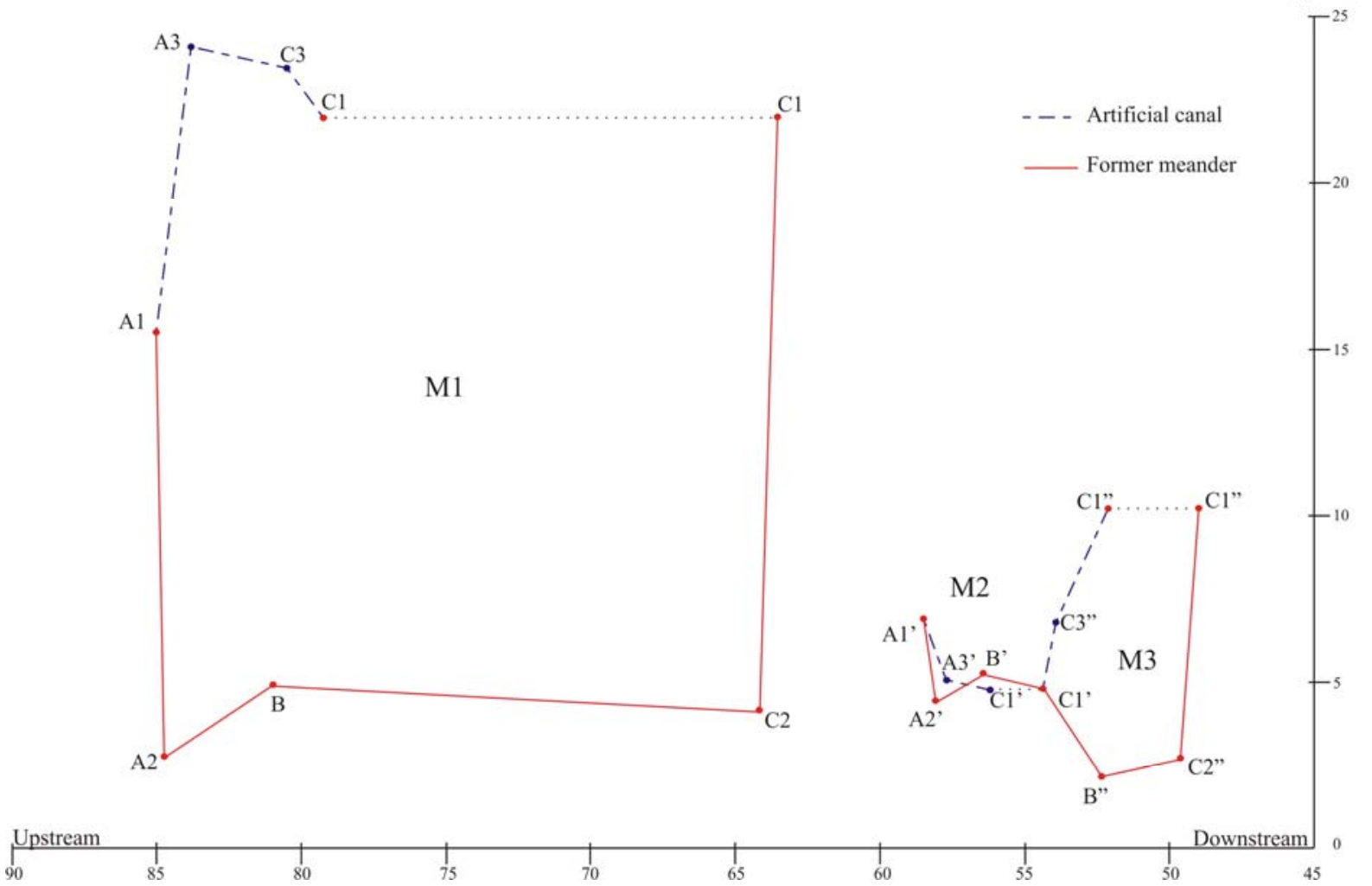

Fig. 8. Mean bed shear stress from estimates with Eq. (3)

The results offer a more continuous view of the variability in the erosion capacity along natural channels and artificial canals. This analysis of potential erosion/deposition reaches is coherent with the values of mean cross sections averaged SSC (Fig. 4) as well as the SS flux analysis supported by the box model (Fig. 5). The decrease in mean SSC up to bifurcations (A2, A2') confirms that sediment deposition mainly occurs in the first half of the former meanders of M1 and M2. In the artificial canals of M1 and M3, the increase in SSC confirms the existence of erosion processes already evidenced as upwelling, sediment-laden plumes originating from the bed. These vertical sediment plumes are associated with high values of $\tau_{0}$ for sections A1, A3, C1, C3, C1", and C3", which allows for the resuspension of the bed material. 


\section{Conclusions}

The evaluation of the meanders evolution after a cutoff program requires an understanding of the critical processes that affect the hydrodynamics and sediment transport within the river system. The contrasted flow and sediment processes in three successive cutoff meanders of the Danube delta were investigated using acoustic and GIS techniques (acoustic Doppler profiling and map/image analyses). The results revealed at the episodic and long-term temporal scales by the combination of these two methods were consistent and complimentary. In the context of an important local human impact as a result of the meander's rectifications in the 1980's the GIS interpretation offered a solid basis for ADCP data interpretation. At the same time, the ADCP and water sampling survey performed during the 2006 flood offered actual data on the distribution of water and suspended-load fluxes through natural and man-made channels. As a consequence of the modified flow pattern, after the cutoff program, the three studied meanders exhibited different responses: on M1, the water flow acceleration in the artificial canal enhanced incision processes, while the liquid and solid fluxes through the former meander were greatly reduced (with sediment deposition processes), especially downstream of the first meander apex. Downstream, meanders M2 and M3 are characterized by the predominance of erosion upstream of the apex and sedimentation downstream, until the confluence, where the dynamics are reactivated. But the combination of all indicators underlines the disparity of operation of both meanders. It finds its explanation first in the unequal distribution of flow between the former meanders and the two artificial channels, which maintains the overall larger dynamics of the former meander M2. The first artificial canal (of M2) is less active than the second one (of M3). Thus, the overall sediment budget, in fact influenced by the artificial canals, has a tendency to erosion in the upstream system and deposition in the downstream system (energy diminished). All these results confirmed the importance of the artificial canals on the geomorphic evolution of the 
three meanders. The unequal repartition of fluxes is in relation with a series of geomorphological control factors: channel length ratio, the diversion angle, sinuosity or bed level difference within each subsystem. Additionally, the predominance of fine and cohesive sediments with low slope and the vegetal coverage of the banks correspond to the moderate dynamics of a river and explain the relative stability of the former meanders after the cut-off program.

Globally, the hydrodynamic conclusions are in good agreement with the GIS interpretations. The study reach has different responses to the implementation of human works, depending on several local factors analysed in this paper.

\section{References}

Bagnold, R.A., 1966. An approach to the Sediment Transport Problem from General Physics. U.S. Geol. Surv. Prof. Pap. 422-I, Washington D.C., 37 pp.

Barbe, D.E., Fago., K., McCorquodale, J.A., 2000. Effects on dredging due to diversions from the lower Mississippi River. Journal of Waterway, Port, Coastal, and Ocean Engineering 126(3), 121129.

Biedenharn, D.S., Thorne, C.R., Watson, C.C., 2000. Recent morphological evolution of the lower Mississippi River. Geomorphology 34, 227-249.

Bondar, C., Panin, N., 2000. The Danube delta hydrologic database and modeling. GeoEcoMarina 5$6,5-52$.

Bridge, J.S., 2003. Rivers and Floodplains: Forms, Processes, and Sedimentary Record. Blackwell Publishing, Oxford. 489 pp.

Constantine, J.A., Dunne, T., Piégay, H., Kondolf, M., 2009. Controls on the alluviation of oxbow lakes by bed-material load along the Sacramento River, California. Sedimentology, 57(2), 389407. 
Dinehart, R.L., Burau, J.R., 2005. Repeated surveys by acoustic Doppler current profiler for flow and sediment dynamics in a tidal river. Journal of Hydrology, 314(1-4), 1-21.

Edmonds, D.A., Slingerland, R.L., 2008. Stability of delta distributary networks and their bifurcations. Water Resources Research, 44, W09426.

Elliott, J. G., Gyetvai, S., 1999. Channel-pattern Adjustments and Geomorphic Characteristics of Elkhead Creek, Colorado, 1937-97. U.S Geological Survey Water-Resources Investigations Report, Denver, Colorado, 99-4098, 39 p.

Ethridge, F.R., Schumm, S.A., 2007. Fluvial seismic geomorphology: a view from the surface. In: Davies, R.J., Posamentier, H.W., Wood, L.J., Cartwright, J.A. (Eds.), Seismic Geomorphology: Applications to Hydrocarbon Exploration and Production. Geological Society, Special Publication 277, London, UK, pp. 205-222.

Gartner, J.W., 2004. Estimating suspended solids concentrations from backscatter intensity measured by acoustic Doppler current profiler in San Francisco Bay, California. Marine Geology 211, 169187.

Hager, W.H., 1984. An approximate treatment of flow in branches and bends. Proceedings of the Institute of Mechanical Engineers, 198, 63-69.

Hood, W.G., 2004. Indirect environmental effects of dikes on estuarine tidal channels: thinking outside of the dike for habitat restoration and monitoring. Estuaries 27, 273-282.

Hood, W.G., 2006. A conceptual model of depositional, rather than erosional, tidal channel development in the rapidly prograding Skagit River delta (Washington, USA). Earth Surface Processes and Landforms 31, 1824-1838.

Hood, W.G., 2010. Delta distributary dynamics in the Skagit River delta (Washington, USA): extending, testing, and applying avultion theory in a tidal system. Geomorphology 12, 154-196.

Hooke, J.M., 1986. Changes in meander morphology. In Gardiner, V. (ed.), International Geomorphology, John Wiley \& Sons, Chichester, 1, 591-609. 
Hughes, M.L., McDowell, P.F., Andrew Marcus, W., 2006. Accuracy assessment of georectified aerial photographs: implications for measuring lateral channel movement in a GIS. Geomorphology 74, 1-16.

Ichim, I., Radoane, M., 1986. Efectele barajelor in dinamica reliefului. Abordare geomorfologica. Editura Academiei, Bucuresti, 157 pp.

Jugaru Tiron, L., Le Coz, J., Provansal, M., Panin, N., Raccasi, G., Dramais, G., Dussouillez, 2009. Flow and sediment processes in a cutoff meander of the Danube delta during episodic flooding. Geomorphology, 106 (3-4), 186-197.

Jugaru, L., Provansal, M., Panin, N., Dussouillez, P., 2006. Apports des Systèmes d'Information Géographiques à la perception des changements morphodynamiques (1970-2000) dans le delta du Danube. Le cas du bras de Saint-George. Geo-Eco-Marina 12, 29-42.

Kesel, R.H., 2003. Human modifications to the sediment regime of the lower Mississippi River flood plain. Geomorphology 56(3-4): 325-334.

Kiss, T., Fiala, K., Sipos, G., 2008. Alterations of channel parameters in response to river regulation works since 1840 on the lower Tisza River (Hungary). Geomorphology 98 (1-2), 96-110.

Knighton, D., 1996. Fluvial Forms and Processes. John Wiley \& Sons, Inc., New York, pp. 94-96.

Kondolf, G.M., Piégay, H., 2003. Tools in Fluvial Geomorphology. Wiley, Chichester, 696 pp.

Kostaschuk, R., Best, J., Villard, P., Peakall, J., Franklin, M., 2005. Measuring flow velocity and sediment transport with an acoustic Doppler current profiler. Geomorphology 68, 25-37.

Land, J., Jones, P.D., 2001. Accoustic measurement of sediment flux in rivers and near-shore waters. In Proceedings of the Seventh Federal Interagency Sedimentation Conference, vol. III. Fed. Interagency Subcomm. On Sediment., Washington, DC, pp. 127-134.

Law, S.W., Reynolds, A.J., 1966. Dividing flow in an open channel. Journal of the Hydraulics Division, American Society of Civil Engineers 92, 207-231.

Le Coz, J., Michálková, M., Hauet, A., Čomaj, M., Dramais, G., Holubová, K., Piégay, H., Paquier, A., 2010. Morphodynamics of the exit of a cut-off meander: experimental findings from field and laboratory studies. Earth Surface Processes and Landforms 35(3), 249-261. 
Leopold, L.B., Wolman, M.G., Miller, J.P., 1964. Fluvial Processes in Geomorphology. Freeman, San Francisco, CA., 522 pp.

Letter, J.V. Jr, Pinkard, C.F. Jr, Raphelt, N.K., 2008. River Diversions and Shoaling. Coastal and Hydraulics Engineering Technical Note ERDC/CHL CHETN-VII-9, U.S. Army Engineering Research and Development Center, Vicksburg, MS.

Leys, K.F., Werritty, A., 1999. River channel planform change: software for historical analysis. Geomorphology 29, 107-120.

Mackey, S.D., Bridge, J.S., 1995. Three-dimensional model of alluvial stratigraphy: theory and application. Journal of Sedimentology Research B65, 7-31.

Miall, A.D., 1996. The Geology of Fluvial Deposits: Sedimentary Facies, Basin Analysis and Petroleum Geology. Springer, New York, 582 pp.

Panin, N., 1976. Some aspects of fluvial and marine processes in Danube delta. Institutul de geologie si geofizica, Anuarul Institutului Geologie si Geofizica L, 149-165.

Panin, N., 2003. The Danube delta. Geomorphology and Holocene evolution: a synthesis. Géomorphologie: Relief, Processus, Environnement 4, 247-262.

Panin, N., Jipa, D., 2002. Danube River sediment input and its interaction with the north-western Black Sea. Estuarine, Costal and Shelf Science 54, 551- 562.

Popa, A., 1997. Environment changes in the Danube delta caused by the hydrotechnical works on the St. George branch. Geo-Eco-Marina 2, 135-147.

Rosgen, D.L., 1994. A classification of natural rivers. Catena 22, 169-199.

Schmitt, L., Maire, G., Humbert, J., 2001. La puissance fluviale: définition, intérêt et limites pour une typologie hydro-géomorphologique de rivière. Z. Geomorphol. N.F. 45(2), 201-224.

Schumm, S.A., 1977. The Fluvial System. Wiley, New York, 338 pp.

Schumm, S.A., 1981. Evolution and response of the fluvial system, sedimentological implications. Society of Economic Paleontologists and Mineralogists Special Publication 31, 19-29.

Schumm, S.A., 1985. Patterns of alluvial rivers. Annual Review of Earth and Planetary Sciences 13, 5-27. 
Shields, F., Abt, S., 1989. Sediment deposition in cutoff meander bends and implications for effective management. Regulated Rivers: Research and Management 4(4), 381-396.

Slingerland, R.L., Smith, N.D., 1998. Necessary conditions for a meandering-river avultion. Geology $26,435-438$.

Syvitski, J.P.M., Kettner, A.J., Correggiari, A., Nelson, B.W., 2005. Distributary channels and their impact on sediment dispersal. Marine Geology 222-223, 75-94.

Tiron, L., 2010. Delta du Danube - Bras de St. George. Mobilité morphologique et dynamique hydrosédimentaire depuis 150 ans. Geo-Eco-Marina Special Publication 4, 280 pp.

Tiron, L., Provansal, M., 2010. Dynamique sédimentaire dans un milieu deltaïque - Le Bras de St. George dans le delta du Danube. Zeitschrift fur Geomorphologie 54(4), 417-441.

Topographical Military Direction, 1970-1972. Topographical maps, 1:50000, sheets L-35-107-C, L35-107-D, Bucharest, Romania.

Topographical Military Direction, 1980-1984. Topographical maps, 1:25000, sheets L-35-107-C-b, L35-107-C-d, Bucharest, Romania.

Vanoni, V.A, 1975. Sedimentation Engineering. American Society of Civil Engineers, New York.

Winer, H.S., Raphelt, N.K., 2005. Mississippi River sediment diversions. In: Proceedings 14th Biennial Coastal Zone Conference, 17-21 July, New Orleans, Baton Rouge, LA.

Wolman, M.G., Miller, J.P., 1960. Magnitude and frequency of forces in geomorphic processes. J. Geology 68(1), 54-74.

Yorke, T.H., Oberg, K.A., 2002. Measuring river velocity and discharge with acoustic Doppler profilers. Flow Measurement and Instrumentation 13(5-6); 191-195. 